\title{
Mind your binomials: a guide to microbial nomenclature and spelling in Sexually Transmitted Infections
}

\author{
Nicola Low, ${ }^{1}$ Kelly Stroud, ${ }^{2}$ David A Lewis, ${ }^{3,4}$ Jackie A Cassell ${ }^{5}$
}

Here is a quick quiz:

Question 1: In which published articles is/are the name of the organism or condition spelled correctly?
A. N. gonorrheae ${ }^{1}$
B. Trichamoniasis ${ }^{2}$
C. Chlamydiae trachomatis ${ }^{3}$
D. Neisseria gonorrhoea ${ }^{4}$
E. Neisseria gonorrhea ${ }^{5}$

Answer: At the end of this piece.

Question 2: Do you like it when someone misspells your name?

Answer: We don't like it and you probably don't either.

There are several reasons for expecting authors to spell scientific terms correctly. First, the conventions for scientific names are meant to allow scientists to communicate precisely and accurately with each other. Incorrect spelling or terminology of the names of microorganisms can cause confusion and perpetuate mistakes. Second, an incorrectly spelled name in the title ${ }^{34}$ of an article means that scientists searching for your article might not find it. Third, and maybe unfairly, poor spelling gives editors and reviewers the impression that you do not know or do not care about the subject of your research.

A quick look at the mistakes made when spelling Neisseria gonorrhoeae and Chlamydia trachomatis suggests that people are confused about when to use the Latin name for the pathogen or its common descriptive name and about differences between UK and US English spelling. It didn't take long to put together the errors listed above, so we conclude that there is a real problem. Now is a good time to remind ourselves of the conventions for using and writing scientific names and to let authors know of our new guidance for

\footnotetext{
${ }^{1}$ Institute of Social and Preventive Medicine, University of Bern, Bern, Switzerland; 'BMJ Publishing Group, London, UK; ${ }^{3}$ Western Sydney Sexual Health Centre, Sydney, New South Wales, Australia; ${ }^{4}$ Centre for Infectious Diseases and Microbiology \& Marie Bashir Institute for Infectious Diseases and Biosecurity, Western Clinical School, University of Sydney, Sydney, Australia; ${ }^{5}$ Department of Primary Care, Brighton and Sussex Medical School, East Sussex, UK

Correspondence to Professor Nicola Low, Institute of Social and Preventive Medicine, Finkenhubelweg 11, University of Bern, Bern, CH-3012, Switzerland; low@ispm.unibe.ch
}

nomenclature and abbreviations for bacteria, protozoa and viruses and the infections they cause.

\section{WHAT IS BINOMIAL NOMENCLATURE?}

All living organisms have two names (binomial) to describe them: a genus (generic name for a group of closely related organisms) and a species (specific name that distinguishes individual types within the group). Knapp et $a l^{6}$ nicely summarised the origins of the system, which were invented by Carl Linnæus, a Swedish botanist in the 18th century. Linnæus suggested two-word 'nomina trivialia' to make it easier to remember the names of organisms, which were originally descriptive phrases ('nomina specifica') that changed as knowledge accrued. The rules for nomenclature have changed over time and differences between zoology, botany and microbiology have emerged. ${ }^{6}$

\section{BACTERIA}

Bacteria have names in Latin. All bacteria are named in five taxonomic categories: class, order, family, genus and species. The genus and species form the binomial that we use to identify the organism (table 1). The name of the genus can come from the person who discovered it, for example, Neisseria, from Albert Neisser, or a characteristic of the organism, for example, Chlamydia, which is Greek for a cloak and describes its intracellular nature. The genus might have more than one distinct species. For example, many species of Neisseria colonise humans and animals, but only two are human pathogens (N. gonorrhoeae and N. meningitidis). ${ }^{7}$ Sometimes, the species can be divided into subspecies. For example, we use the binomial Treponema pallidum to refer to the sexually transmitted infection syphilis, but there are three subspecies: T. pallidum subspecies pallidum causes syphilis; T. pallidum subsp. pertenue causes yaws; and T. pallidum subsp. endemicum causes bejel. ${ }^{8}$ Chlamydia is a bacterium with a contentious taxonomic history, having been called Miyaganawella, Bedsonia and Rakeia in the past, ${ }^{9}$ and having initially been thought to be a virus ${ }^{10}$ or a protozoan. ${ }^{11}$

\section{VIRUSES}

Virologists have adopted different criteria for nomenclature, partly because viruses are not living organisms. ${ }^{12}$ Viruses often have names in English, for example hepatitis B virus, but they can also have Latin names, for example herpes simplex virus (herpes comes from the Greek herpein, to creep). The generic names of viruses such as HIV are not written in italics; italics are only used for the virus species name or its family. They are not capitalised unless the name is a proper noun, for example Ebola virus.

\section{WHOSE RESPONSIBILITY IS IT TO GET THE NAME RIGHT?}

Authors probably expect copy editors to correct their spelling and editors expect authors to proofread carefully. As our published examples show, failures at both stages result in errors in the printed version. But getting to print is the end of a long process and editors and reviewers will read a manuscript before it is accepted. Authors are responsible for checking their spelling and terminology before submitting a manuscript. First impressions are important so it makes sense to get the spelling and formatting right before submission.

Table 1 Nomenclature for bacteria and general principles for formatting

\begin{tabular}{|c|c|c|}
\hline & Formatting & Example \\
\hline Genus & Italicised, uppercase first letter & Neisseria \\
\hline Species & Italicised, lowercase & gonorrhoeae \\
\hline Condition & $\begin{array}{l}\text { Not italicised, lowercase except when used } \\
\text { at start of a sentence }\end{array}$ & gonorrhoea (UK), gonorrhea (US) \\
\hline $\begin{array}{l}\text { Abbreviation } \\
\text { of genus }\end{array}$ & $\begin{array}{l}\text { May be used when several species from the } \\
\text { same genus are being named or the same } \\
\text { species is mentioned repeatedly. Write the } \\
\text { genus in full the first time, then abbreviate } \\
\text { with a full stop after the initial }\end{array}$ & $\begin{array}{l}\text { "The sample contained Neisseria gonorrhoeae, } \\
\text { N. meningitidis and N. lactamica" }\end{array}$ \\
\hline $\begin{array}{l}\text { Unknown } \\
\text { species }\end{array}$ & $\begin{array}{l}\text { If the precise species is not known, use sp. } \\
\text { If there is more than one species, use spp. }\end{array}$ & $\begin{array}{l}\text { "The condition was caused by a Neisseria sp." } \\
\text { "They identified several Neisseria spp. in the } \\
\text { sample" }\end{array}$ \\
\hline
\end{tabular}


Table 2 Organism names and abbreviations for bacteria and protozoa

\begin{tabular}{|c|c|c|c|c|}
\hline Binomial name & Genus & $\begin{array}{l}\text { Abbreviation of } \\
\text { organism name }\end{array}$ & Condition* & $\begin{array}{l}\text { Abbreviation of } \\
\text { infection name }\end{array}$ \\
\hline Chlamydia trachomatis & Chlamydia & C. trachomatis & Chlamydia & СТ \\
\hline Mycoplasma genitalium & Mycoplasma & M. genitalium & M. genitalium infection $\ddagger$ & MG \\
\hline Neisseria gonorrhoeae§ & Neisseria & N. gonorrhoeae & Gonorrhoea§ & NGף \\
\hline Treponema pallidum & Treponema & T. pallidum & Syphilis & TP \\
\hline Trichomonas vaginalis & Trichomonas & T. vaginalis & Trichomoniasis & TV \\
\hline
\end{tabular}

${ }^{*}$ Only capitalise first letter if used at the start of a sentence, otherwise lowercase.

tIn general, we discourage the use of abbreviated names for conditions. These abbreviations can be used in tables and figures where space is limited. They still need to be spelled out at the first use.

†There is no agreed name at present.

§Please note the ' $\mathrm{e}$ ' at the end of the Latin species name. There is no ' $\mathrm{e}$ ' at the end of the name of the condition. We use UK English spelling, which has an extra 'o' in the name of the condition.

IGC cannot be used to abbreviate Neisseria gonorrhoeae. GC is used mainly in the UK as an abbreviation of gonococcus, the shape of the bacterium (see table 3).

Table 3 Adjectives for describing shapes of bacteria

\begin{tabular}{lllll}
\hline Shape singular/plural & Description & Example & Plural & Adjective \\
\hline Coccus/cocci & Spherical bacteria; can be in pairs (diplococci) & Gonococcus & Gonococci \\
or chains (streptococci) & Pneumococcus & Pneumococci & Ponococcal \\
Bacillus/bacilli* & $\begin{array}{l}\text { Rod-shaped bacteria } \\
\text { Spiral }\end{array}$ & Spiral-shaped bacteria & Spirochaetet & Spirochaetes \\
\hline
\end{tabular}

*Not to be confused with Bacillus the genus.

tMost common example for sexually transmitted pathogens, that is, Treponema pallidum. Alternative forms are vibrio and spirillum.

\section{ADVICE FOR AUTHORS}

Editors and production staff at Sexually Transmitted Infections have come up with some guidance for authors (tables 1,2 and 3). This combines published conventions for scientific nomenclature, summarised by the journal Emerging Infectious Diseases, ${ }^{13}$ and the opinions of the editors. We try to cover spelling and abbreviations of both organisms and conditions for the most common sexually transmitted infections (table 2).

We have posted the guidance in our Instructions for Authors on the submission website (http://sti.bmj.com/site/about/ guidelines.xhtml) and we hope you find it useful. Please follow our guidance for all your future submissions.

Answer: all are incorrect (see table 2 for the correct spelling).

Acknowledgements We would like to thank Yen Chau of the BMJ Production Team for helping to refine the guidance and for implementing it.

Contributors NL had the idea for the editorial and drafted it; KS drafted the tables for the production team; DL gave expert microbiological advice and JC commented on the draft. All authors approved the final version and endorse the guidance.

Competing interests None.
Provenance and peer review Commissioned; internally peer reviewed.

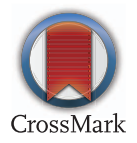

To cite Low N, Stroud K, Lewis DA, et al. Sex Transm Infect 2015;91:154-155.

Received 6 November 2014

Accepted 9 November 2014

Published Online First 16 December 2014

Sex Transm Infect 2015;91:154-155.

doi:10.1136/sextrans-2014-051937

\section{REFERENCES}

1 Grad YH, Kirkcaldy RD, Trees D, et al. Genomic epidemiology of Neisseria gonorrhoeae with reduced susceptibility to cefixime in the USA: a retrospective observational study. Lancet Infect Dis 2014;14:220-26.

2 Kalichman SC, Pellowski J, Turner C. Prevalence of sexually transmitted co-infections in people living with HIV/AIDS: systematic review with implications for using HIV treatments for prevention. Sex Transm Infect 2011;87:183-90.

3 Kersaudy-Rahib D, de Barbeyrac B, de Diego S, et al. Home screening compared with clinic-based screening for Chlamydiae trachomatis in France: a randomised controlled trial. Lancet 2013;382:S53.

4 Turner KME, Round J, Horner P, et al. An early evaluation of clinical and economic costs and benefits of implementing point of care NAAT tests for Chlamydia trachomatis and Neisseria gonorrhoea in genitourinary medicine clinics in England. Sex Transm Infect 2014;90:104-11.

5 Huppert JS, Taylor RG, St Cyr S, et al. Point-of-care testing improves accuracy of STI care in an emergency department. Sex Transm Infect 2013;89:489-4.

6 Knapp S, Lamas G, Lughadha EN, et al. Stability or stasis in the names of organisms: the evolving codes of nomenclature. Philos Trans R Soc Lond B Biol Sci 2004;359:611-22

7 Bennett JS, Jolley KA, Earle SG, et al. A genomic approach to bacterial taxonomy: an examination and proposed reclassification of species within the genus Neisseria. Microbiol 2012;158(Pt 6):1570-80.

8 Lukehart SA. Biology of treponemes. Chapter 36 In: Holmes KK, Sparling PF, Stamm WE, Piot P, Wasserheit JN, Corey L, Cohen MS, Watts DH, eds. Sexually Transmitted Diseases. 4th edn. New York: McGraw-Hill Medical, 2008:647-59.

9 Bavoil P, Kaltenboeck B, Greub G. In Chlamydia veritas. Pathog Dis 2013;67:89-90.

10 Clarke IN. Evolution of Chlamydia trachomatis. Ann NY Acad Sci 2011;1230:E11-18.

11 Schachter J, Stephens RS. Biology of Chlamydia trachomatis. Chapter 31. In: Holmes KK, Sparling PF, Stamm WE, Piot P, Wasserheit JN, Corey L, Cohen MS, Watts DH, eds. Sexually Transmitted Diseases. 4th edn. New York: McGraw-Hill Medical, 2008:555-76.

12 Van Regenmortel MH. On the relative merits of italics, Latin and binomial nomenclature in virus taxonomy. Arch Virol 2000;145:433-41.

13 Centers for Disease Control and Prevention. Scientific Nomenclature. Secondary Scientific Nomenclature 2010. http://wwwnc.cdc.gov/eid/page/ scientific-nomenclature (accessed 2 Dec 2014). 